\title{
Governing borderless climate risks: moving beyond the territorial framing of adaptation
}

\author{
Magnus Benzie ${ }^{1}$ Åsa Persson ${ }^{1,2}$
}

Accepted: 23 May 2019 / Published online: 30 May 2019

(c) The Author(s) 2019

\begin{abstract}
Despite the increasing relevance of cross-border flows of goods, capital and people in shaping risks and opportunities today, we still live in a "bordered" world, where the nation state plays a key role in planning and governance. Yet, climate change impacts will not be contained within country borders, meaning that climate change adaptation governance should also consider "borderless climate risks" that cascade through the international system, in relatively simple or highly complex ways. In this paper, we demonstrate how the notion of borderless climate risks challenges the dominant territorial framing of adaptation and its problem structure. To advance knowledge, we ask: why has a territorial framing and the national and sub-national scales dominated adaptation governance? How do borderless climate risks challenge this framing and what are possible governance responses? We draw on constructivist international relations theory and propose that the epistemic community that developed to interpret climate change adaptation for decision-makers had certain features (e.g. strong environmental sciences foundation, reliance on place-based case study research) that established and subsequently reinforced the territorial framing. This framing was then reinforced by an international norm that adaptation was primarily a national or local responsibility, which has paradoxically also informed calls for international responsibility for funding adaptation. We conclude by identifying types of governance responses at three different scales — national and bilateral; transnational; international and regionaland invite more systematic evaluation by the IR community.
\end{abstract}

Keywords Climate risk - Climate change adaptation · Governance $\cdot$ Epistemic community Norms $\cdot$ UNFCCC

$\begin{array}{ll}\text { Abbreviations } \\ \text { COP } & \text { Conference of the Parties } \\ \text { GPG } & \text { Global public good } \\ \text { IPCC } & \text { Intergovernmental Panel on Climate Change } \\ \text { IR } & \text { International Relations } \\ \text { IVA } & \text { Impacts, vulnerability, adaptation }\end{array}$

Magnus Benzie

magnus.benzie@sei.org

1 Stockholm Environment Institute, Box 24218, 10451 Stockholm, Sweden

2 Department of Thematic Studies, Linköping University, 58183 Linköping, Sweden 


$\begin{array}{ll}\text { NAP } & \text { National Adaptation Plans } \\ \text { NAPA } & \text { National Adaptation Programmes of Action } \\ \text { NAS } & \text { National adaptation strategies } \\ \text { NC } & \text { National Communication } \\ \text { RBO } & \text { River basin organization } \\ \text { UNFCCC } & \text { United Nations Framework Convention on Climate Change }\end{array}$

\section{Introduction}

Globalization and the importance of borders and nation states have re-entered public debates and imagination in recent years. Whereas some political movements favour a retreat from multilateralism, unprecedented international connectivity is one of the defining features of the modern world, as well as an objective for many community, country and business leaders around the world (Khanna 2016). Globalization and hyperconnectivity present a challenge to strategic planners; how can and should countries act independently, divide responsibilities among themselves and coordinate their efforts to manage "borderless risks" (Goldin and Mariathasan 2014)?

While climate change is in many regards recognized as a truly global and interconnected challenge, the vast majority of scholarship on climate change adaptation has so far largely neglected this governance challenge. Instead, research and practice on adaptation has typically framed climate change impact and vulnerability as highly localized phenomena (see Barrett 2008; Persson 2011; Khan 2013; Nalau et al. 2015; Magnan and Ribera 2016). Such a framing implies a corresponding need for territorial adaptation governance, in the sense of focusing governance efforts on direct climate impacts within the jurisdiction to contain and adapt to them within territorial borders. Arguably, current adaptation governance thinking posits that adaptation options will and should be understood and developed at national or sub-national levels, and, at most, funded via international institutions. This approach to problem structure assumes that actors can adapt in isolation, but this assumption contrasts with emerging evidence of borderless climate risks (Challinor et al. 2017; Hedlund et al. 2018; Schenker 2012; Otto et al. 2017; Bailey and Wellesley 2017). Little consideration has been given in the climate change adaptation literature to possible governance approaches for managing climate risk inter-, trans-, or supra-nationally, at bilateral, regional or even global scales (see Persson and Dzebo 2019).

This paper asks: why has a territorial framing and the national and sub-national scales dominated adaptation governance? How do borderless climate risks challenge this framing and what are possible governance responses? We define adaptation governance as the collective efforts of multiple societal actors to address problems, or to reap the benefits, associated with the impacts of climate change, including the design and use of institutions and the ideas providing a normative underpinning (after Huitema et al. 2016). To explain the origin and dominance of the territorial perspective and the focus on national and sub-national adaptation governance, we draw on constructivist international relations (IR) theory. In particular, we use the concepts of epistemic communities (Haas 1992) and norm emergence and institutionalization (Finnemore and Sikkink 1998; Bernstein 2013). We then call for more engagement by IR scholarship by outlining possible governance responses to borderless climate risks, organized under three scales: national and bilateral; transnational; and international and regional responses. 
Apart from an extensive literature review, this review paper is based on interviews and policy document analysis conducted over the last ten years by both authors as reported in Persson et al. (2009), Remling and Persson (2015), Hall and Persson (2018), Runhaar et al. (2018), Hedlund et al. (2018), Benzie (2014), Benzie and John (2015) and Benzie et al. (2018), and participant observations by both authors at seven Conference of the Parties (COP) meetings of the United Nations Framework Convention on Climate Change (UNF$\mathrm{CCC}$ ), Adaptation Futures conferences, and other adaptation-related science and policy meetings since 2007.

We aim to make two contributions to the adaptation governance literature generally and this Special Issue specifically. Although there is a growing literature on the importance of borderless climate risks, we offer distinct explanations why a territorial perspective has dominated for so long and, by doing so, pointing at what ideas and practices need to be overcome for their systematic consideration. Second, IR perspectives are increasingly being applied when engaging with the long understudied field of climate change adaptation and borderless climate risks (see e.g. Khan 2013; Biermann 2014; Moore 2012; Ciplet 2015; Hall and Persson 2018). However, we try to outline a range of possible governance options, at various levels (not just international), for a more complete analysis (see also Banda 2018).

We first provide a brief overview of dominant scales of adaptation governance, followed by an overview of borderless climate risk and their potential significance. This is followed by an application of the epistemic communities and norm diffusion concepts, to explain why a territorial framing has been so dominant. We then look to the future and identify current efforts to better consider borderless climate risks, to then discuss possible governance responses at different levels and scales and in relation to different IR perspectives.

\section{Scales of adaptation to climate change}

\subsection{Scales and framing of adaptation governance}

Looking at dominant conceptualizations of adaptation, the Intergovernmental Panel on Climate Change (IPCC) Third Assessment Report defined it as an "adjustment in natural or human systems in response to actual or expected climatic stimuli or their effects, which moderates harm or exploits beneficial opportunities" (IPCC 2001, p. 982). This classic definition, which endured largely unchanged across the subsequent two assessment reports (IPCC 2007, 2014), does not specify the scale at which either the "adjustment" or "effects" will operate. Likewise there is nothing inherent in the definition of climate change impacts that specifies scale. There is therefore nothing about adaptation a priori that requires either a local or spatially connected framing or interpretation.

The multi-scale nature of the adaptation challenge is widely recognized in the adaptation literature (Adger 2001; Adger et al. 2005; Keskitalo 2010; Juhola et al. 2011; Noble et al. 2014; Termeer et al. 2016). It implies that adaptation requires governance across multiple administrative levels, to facilitate effective actions and sustainable outcomes. Yet, while the need for multi-level governance is widely recognized, adaptation governance to date has been strongly focused on the national or sub-national levels (see below; Lesnikowski et al. 2016). This has manifested in two ways. First, most adaptation planning and governance is undertaken by national-level institutions (Challinor et al. 2018). Second, to the extent that institutions across levels (international, regional, national, sub-national) 
develop and implement adaptation policy, Banda (2018, p. 1048) argues such policy has a "decidedly mono-scalar" spatial focus on the domestic scale (national and sub-national).

The IPCC Assessment Reports constitute an indicator of this trend. The 2001 Third Assessment Report did not include many empirical examples of adaptation governance and did not discuss scale or level of adaptation planning or governance explicitly (Smit and Pilifosova 2001). The 2007 Fourth Assessment Report had only one chapter on adaptation, which discussed "adaptation practices" generally and without a specific focus on scale, but with a strong national focus in the empirical examples cited (Adger et al. 2007). The 2014 Fifth Assessment Report included more examples and case studies, and conceived adaptation planning as "occur[ring] at a number of spatial scales including at the national, regional, city, district, or local community level" (Noble et al. 2014, p. 849) - thus, notably, missing scales above the national. Looking at empirical evidence, it further noted that "[i]n particular, there is substantial progress in development of national adaptation strategies and plans" (Mimura et al. 2014, pp. 873-874).

National adaptation planning and governance is indeed increasing in response to a steadily growing climate change awareness. OECD countries have increasingly adopted national adaptation strategies (NASs) (see Ford et al. 2015; OECD 2015; Bauer et al. 2012). Under the UNFCCC, many developing countries are now in the process of developing National Adaptation Plans (NAPs) (UNFCCC 2015), which is a planning instrument succeeding the National Adaptation Programmes of Action (NAPAs) (UNFCCC 2016). The 2015 Paris Agreement introduced a new national reporting mechanism, "adaptation communications" (Art. 9 and 10). The spending of multilateral funds (e.g. Adaptation Fund, Green Climate Fund, Pilot Program on Climate Resilience) on adaptation projects on the ground in developing countries also confirms that adaptation is taking place at the national and local levels. In terms of multi-level governance, coordination between national and sub-national levels has received specific attention in research (Dovers and Hezri 2010; Amundsen et al. 2010; Nalau et al. 2015; Huitema et al. 2016).

Looking above the national level, some references to supra-national scales can be found in the adaptation literature (Keskitalo 2009; O'Brien and Leichenko 2000), but in general these are not well elaborated in terms of governance functions. One exception may be found in the literature that contemplates the governance of adaptation within the European Union (Keskitalo 2010; Glaas and Juhola 2013; Biesbroek et al. 2010; Remling 2018), which constitutes an almost unique experiment of how a supra-national body can define a role for itself in governing the adaptation activities of its member states and of communities within those states, including cross-border regions, such as the Alps, Mediterranean Sea or Baltic Sea regions (EEA 2017). Other regional examples include the South Pacific Regional Environment Programme and the Caribbean Catastrophic Risk Insurance Facility. However, to the extent that regional organizations are involved in adaptation governance, it is usually as an agent of knowledge exchange between member countries, facilitating "good practice" based on national or sub-national case studies, for example the regional adaptation networks coordinated by the UN. ${ }^{1}$ In other words, adaptation governance at regional or international level still has a domestic policy focus (Banda 2018). In contrast, it is rare to identify cases of regional cooperation to jointly manage shared climate risks that cross borders.

Overall, despite growing activity around climate change adaptation at multiple levels, the focus of these efforts has been almost exclusively national or sub-national in scale and

\footnotetext{
1 For more information on the regional adaptation networks, see the Global Adaptation Network website, hosted by UNEP at: http://ganadapt.unep.org/index.php/regional-networks.
} 
the framing has been territorial and place-based. Even in cases that one might expect to offer precedents for governing borderless risks, for example where institutions already exist to manage cross-border risks, such as river basin organizations (RBOs) in transboundary river basins, co-governance of climate risks is rare (Blumstein et al. 2016). Additionally, even where governance instruments exist to facilitate cross-border collaboration for adaptation, for example the provision within international adaptation finance mechanisms such as the Adaptation Fund, the overwhelming majority of projects are national or local, rather than regional. ${ }^{2}$

\subsection{Borderless climate risks}

With the territorial framing of adaptation, the focus is on direct climate risks in a given place. In light of borderless climate risks, this framing is increasingly argued to be insufficient; the additional potential benefits - and beneficiaries - of adaptation, beyond local and national scales, are not addressed. Indeed, a territorial framing, with nationally or locally scaled adaptation, may even be futile or harmful (Banda 2018) and serve to "inadvertently increase systemic risk" (Committee on Climate Change and China Expert Panel on Climate Change 2018). Challinor et al. (2017, p. 621) argue that national assessments of climate risk and adaptation have "major blind spots concerning the interaction and amplification of risks and their international dimensions".

So, what are borderless climate risks, and how significant might they be compared with direct climate risks within borders? The emerging literature offers concrete examples. Two of the most common risks identified are food security, through climate-induced disruptions in global food supply chains, and cross-border climate-induced population displacement and migration (Challinor et al. 2017; Smith et al. 2018). The 2010-2011 global food price crisis is commonly identified as the clearest example of a food security risk with a climate dimension. Regarding displacement and migration, recent cases in the USA (New Orleans), Pakistan and Syria are commonly cited examples. Media reports are now linking migration flows from Central America to the US as climate change related (Blitzer 2019). Water scarcity, in terms of climate-induced water shortages in transboundary watersheds and river basins, is another frequently cited and well-established risk (Challinor et al. 2018; Banda 2018; Wilder et al. 2010; Tigre 2019). In terms of ecosystem shifts and extraction of natural resources, climate-induced species range shifts can be considered a borderless climate risk (Oppenheimer et al. 2014), which is now being linked to international conflict in the field of fisheries and marine animal distribution (Pinsky et al. 2018). Climate-induced human health risks, such as the accelerated spread of vector-borne diseases, have been identified to have potentially cross-border effects (Committee on Climate Change and China Expert Panel on Climate Change 2018). Overall, these risks can propagate through different pathways: biophysical, trade, financial flows and people, for example (Hedlund et al. 2018).

Diverse concepts and terminologies, drawing on different disciplinary fields, are used in the academic and policy literature. Considering the broader picture, it has been referred to as "the international dimension of climate change" (Sentance and Betts 2012) and "the global context for local impacts" (Liverman 2015). Economic modelling and assessment

\footnotetext{
2 By April 2019, 8 out of a total 113 projects funded by the Adaptation Fund since its inception were classified by them as regional in scale, i.e. 7\%. See https://www.adaptation-fund.org/projects-programmes/proje ct-information/projects-table-view/.
} 
Table 1 Top 20 most exposed countries from the TCI Index, based on Hedlund et al. (2018)

\begin{tabular}{|c|c|c|c|c|c|c|c|}
\hline Rank & Country & TCI Index score & Region & Rank & Country & TCI Index score & Region \\
\hline 1 & Jordan & 8.11 & MENA & 11 & Egypt & 6.78 & MENA \\
\hline 2 & Lebanon & 7.86 & MENA & 12 & Gambia & 6.75 & SSA \\
\hline 3 & Kuwait & 7.57 & MENA & 13 & Togo & 6.63 & SSA \\
\hline 4 & United Arab Emirates & 7.43 & MENA & $=14$ & Tajikistan & 6.56 & $\mathrm{CE} \& \mathrm{C}$ \\
\hline 5 & Sudan & 7.14 & SSA & $=14$ & Swaziland & 6.56 & SSA \\
\hline 6 & Netherlands & 7.11 & Eur & 16 & Liberia & 6.44 & SSA \\
\hline$=7$ & Mauritania & 7 & SSA & $=17$ & Portugal & 6.33 & Eur \\
\hline$=7$ & Belgium & 7 & Eur & $=17$ & Kenya & 6.33 & SSA \\
\hline$=7$ & Luxembourg & 7 & Eur & $=19$ & Maldives & 6.29 & SIDS \\
\hline 10 & Malaysia & 6.89 & SE Asia & $=19$ & Montenegro & 6.29 & Eur \\
\hline
\end{tabular}

Several regions are represented: MENA Middle East and North Africa, SSA Sub-Saharan Africa, Eur Europe, SE Asia South East Asia, CE\&C Central Asia and the Caucasus, SIDS Small Island Developing States. In comparison, only three regions feature in the top 20 ranked countries of the ND-GAIN index (a popular measure of territorial or direct vulnerability): SSA, MENA and SIDS (Hedlund et al. 2018)

have used the terms "secondary effects", "international spillovers" or "cross-boundary spillovers" (Hunt et al. 2009; Schenker 2012; Roggero et al. 2019). In the climate impacts literature, and the IPCC Fourth Assessment Report specifically, the effects have been referred to as "indirect, trans-boundary and long-distance" (Oppenheimer et al. 2014). Whereas transboundary effects are transmitted over borders between neighbouring countries, "teleconnected" impacts result from more remote links over great distances (Moser and Hart 2015; Hedlund et al. 2018). Finally, in the literature on global risk, we find terms such as "systemic risk", "globally networked risks" and "cascading effects" (see e.g. Helbing 2013; Galaz et al. 2017; Walker et al. 2009) to denote risk that "may be triggered by concurrent or sequential hazards - which may be chronic or acute in nature-and propagated across time and space where human systems and responses to a trigger amplify rather than dampen the risks" (Committee on Climate Change and China Expert Panel on Climate Change 2018, p. 98). Here, we use the broad term borderless climate risk, to denote any climate risk that crosses national borders in its transmission, whether in a transboundary or teleconnected way. This term does not include systemic risk with cascading effects between sectors that stay within national borders.

Due to methodological barriers, it is difficult to assess the significance and cost of omitting borderless climate risk when planning and governing adaptation. However, existing models and evidence suggest that costs can be significant and even in the same order of magnitude as the direct impacts facing a country (Schenker 2012; Paul Watkiss Associates 2012) — or even higher for some developed countries (PWC 2013). A recent assessment concluded that "the likelihood and costs of [climate-related] systemic risk tend to be understated" (Committee on Climate Change and China Expert Panel on Climate Change 2018 , p. 137). Another study of critical "chokepoints" in global food trade concluded that climate change is increasing the risk that these chokepoints will be disrupted, implying significant global cascading effects (Bailey and Wellesley 2017).

Importantly, borderless climate risk is not an exclusively or even predominantly rich country problem, although high-income countries have generally advanced further in assessing them. By constructing an index of country exposure to "transnational climate 
impacts", Hedlund et al. (2018) find that many low-income countries are highly exposed. The top twenty most exposed countries are an eclectic mix of Middle Eastern, Sub-Saharan African and small European countries (Table 1). Of special concern is that some lowincome, fragile states in Sub-Saharan Africa are suffering "double exposure" to both direct climate impacts and borderless climate risk.

The increasing significance of borderless climate risk points towards a paradox in the way climate change is framed. On the one hand, climate change is held up as the archetype of a truly "global" problem (see e.g. Barrett 2007). And yet, the problem that we need to adapt to is usually seen as a local phenomenon, or locally manifested. Without denying the local manifestation of climate change, this paper seeks to shine a light on the connections between places that make the problem of adaptation something more than just a local problem.

\section{Why has adaptation been framed as a territorial issue?}

Before discussing the implications of borderless climate risks for adaptation governance, and charting paths forward, it is necessary to understand why adaptation research and practice adopted a territorial framing to begin with. This will help elucidate what institutions and practices would need to be changed in order to better incorporate borderless climate risk. Here, we draw on constructivist IR and use two well-established concepts: epistemic communities, and norm emergence and institutionalization.

\subsection{The emergence of an epistemic community around adaptation}

An epistemic community is defined by Haas (1992, p. 3) as "a network of professionals with recognized expertise and competence in a particular domain and an authoritative claim to policy-relevant knowledge within that domain or issue-area". This is a useful concept for explaining the (non-)formation of international and transnational governance responses under conditions of uncertainty, such as for climate change, since "how states identify their interests and recognize the latitude of actions deemed appropriate in specific issue-areas of policymaking are functions of the manner in which the problems are understood by the policymakers or are represented by those to whom they turn for advice under conditions of uncertainty" (p. 2). Professionals in an epistemic community share normative and causal beliefs, notions of validity, and a common policy enterprise. The role of the community in policy coordination is to articulate the cause-and-effect relationship of complex problems, help states identify their interests, frame the issues for collective debate, propose specific policies, and identify salient points for negotiation-in a process moving from uncertainty, through interpretation, to institutionalization.

We propose that an epistemic community of adaptation scholars and planners developed relatively quickly starting in the 1990s, with the IPCC process as an important forum. It managed to institutionalize its policy claims, which were almost exclusively concerned with direct, local impacts and territorial adaptation. A set of circumstances then reinforced this dominant interpretation, and not until relatively recently has the community diversified and fragmented.

Climate change impacts, vulnerability and adaptation (or "IVA") is a relatively young research field, which was charged with quickly moving from uncertainty to interpretation. The first two IPCC Assessment Reports had no dedicated assessment of adaptation (McG 
Tegart et al. 1990; Watson et al. 1995). It was not until the third Assessment Report in 2001 that Working Group II was dedicated exclusively to impacts, vulnerability and adaptation (McCarthy et al. 2001), recognizing both the increasing policy relevance of such research, as well as a substantial growth in content.

The rapidity of the rise in IVA research, mediated through the IPCC, is important because the problem framing that emerged in the early period has dominated and shaped the field (Grothmann 2014; Moore 2012). An "impact" approach came to dominate adaptation rather than a "vulnerability" approach (Schipper and Burton 2009). Further, early on, climate change was labelled as an environmental problem (Incropera 2015). Environmental sciences played a large role in bringing climate change science to the attention of policymakers. They also played a large role in early efforts to explore the potential impacts of climate change. In particular, the insights provided by modelling studies dominated early scientific innovations and policy discussions (see also Mahony and Hulme 2012). The shared causal belief was that better climate impact knowledge was a critical factor for adaptation and it was thus seen as a key objective in adaptation governance.

Early IPCC and national assessments of climate change impacts typically focused on issues such as flooding and drought, crop failure, heat stress, changing disease patterns, biodiversity loss and critical infrastructure failure, reflecting the intersection of research generated by hydrology, agriculture science, biology and engineering departments, and their integration with climate modelling. For example, hydrological models and ecosystem models made use of new projections of changes in temperature, precipitation and humidity from global climate models. In terms of proposing policies, a combination of engineering and infrastructure adaptations, alongside more traditional environmental interventions, was assumed to offer solutions to climate risk. To address national and sub-national impacts and adaptation options, the epistemic community tended to promote downscaling of global climate models where the "system boundary" was defined as the national border, if not a more local scale, thus perpetuating the impacts-focused, territorial approach to adaptation as a "local" undertaking (cf. Weisser et al. 2014).

A number of factors contributed to further institutionalizing and reinforcing this approach. Early insights into climate impacts were first adopted by environment ministries (as opposed to the finance, foreign affairs, trade, civil affairs), who typically held responsibilities for managing ecosystems and water resources, while being staffed by individual experts who were familiar with the results of environmental sciences (see also Massey and Huitema 2012). As Haas (1992) notes, "professionalized bureaucracies" are more likely to seek, reinforce and act on knowledge that is familiar to them. It would be some years before social sciences engaged meaningfully in climate impacts research, by which time the "environmental" character of climate change adaptation had to some extent been institutionalized.

Further, there has also been a big focus in the adaptation field on peer-to-peer learning and case study research, particularly in policy-facing projects, which indicates a shared notion of validity. For example, national and local governments often emulated the approach of early movers and peers that were seen as "successful" (Ribeiro et al. 2009). Some countries established learning platforms for adaptation that provided data and information about climate impacts and developed and shared case studies as a key learning tool, for example the UK Climate Impacts Programme and KomPass in Germany. Multiple similar learning platforms have been set up by the UNFCCC and other international organizations (Hall and Persson 2018). Given the relative novelty of the adaptation policy challenge, case study-based learning is logical, but it reinforces current practices, including the territorial approach. 
Perpetuating this trend, adaptation research has increasingly striven to be demand-led (Klein and Juhola 2014). Again, while suitable for many reasons, the demand for adaptation knowledge largely came from a limited group of environmental policy-makers and bureaucrats. There has been a seemingly strong preference shown by decision-makers for quantitative information as a way to reduce uncertainty, which may have guided attention to more easily quantifiable impacts. This reflects many trends, including pressure on decision-makers to pursue "evidence-based" policies, the tradition of relying on quantitative analysis in environmental sciences, and the "reassurance of numbers" when dealing with the level of uncertainty implied by future climate change. Commenting on climate change more broadly, Mahony and Hulme (2012, p. 197) argue there has been an "epistemic hegemony of [model-based] simulation". Finally, the focus on direct and local impacts in adaptation planning may also be explained by the traditional technocratic and "depoliticized" approach adopted by many countries in which adaptation was separated from processes of social change (Schultz and Siriwardane 2015; Remling 2018).

In summary, the epistemic community that evolved around adaptation was a multi-disciplinary and innovative science-policy endeavour, but rooted in environmental sciences. As a result, its focus was on local impacts and territorial adaptation. Its authoritative claim to policy-relevant knowledge meant that governance responses to borderless climate riskswhether at supranational level or unilateral action by states-were not defined as critical to state interests. As a consequence, adaptation governance at levels above the national has been weak (see Hall and Persson 2018).

The character of this epistemic community was appropriate in many ways (direct and local climate impacts are severe and require adaptation), but it was not inevitable. Alternative disciplines, such as systems theory, network analysis, macro-economics, agent based modelling, foresight science, human geography and political science, could have been utilized more to explore the nature of vulnerability to climate change or the scope of adaptation, in ways that may have embraced borderless climate risks. The relative absence of strong rival claims to knowledge explains why the territorial adaptation epistemic community was so effective and influential during this formative period: "[i]n less politically motivated cases, epistemic communities have a greater hand in the various stages of the policymaking process" (Haas 1992, p. 16).

Once epistemic communities are established, Haas points out their "reluctance to deal with policy agendas outside their common policy enterprise" (1992, p. 20). Only relatively recently has demand for knowledge about borderless climate risk and associated adaptation options accelerated among policy-makers. Indeed, it is important to recognize that epistemic communities evolve and that "progressively more accurate characterizations of the world are consensually formulated" over time (ibid., p. 23). The sixth IPCC Assessment Report due in 2021 will be an important indicator of such a changing framing.

\subsection{Institutionalizing the norm that adaptation is a local and national responsibility}

Once an issue has been interpreted and framed by an epistemic community, its institutionalization can also be studied as a process of norm emergence and diffusion at the level of international institutions. The role of norms for encapsulating and embedding framings of problems within international treaties and declarations has been widely studied in the global environmental governance literature, but less examined in the field of climate change adaptation (for an exception, see Moore 2012). 
Norms define appropriate behaviour of actors and asign rights and responsibilities, and, as such, have constitutive, regulative and deontic functions (Finnemore and Sikkink 1998; Bernstein 2013). They further legitimate and delegitimate institutional forms. Norms emerge and diffuse at multiple levels, but "the importance of norms in global politics comes from their institutionalization, which makes them 'collective' or part of social structure" (Bernstein 2013, p. 128). The degree of institutionalization determines how likely it is that the norm is contested and "the ability of the norm to (re)define state or other key actors' interests” (ibid.). Importantly, norms can not only produce desirable results and underpin strong institutions, but can also produce undesirable results and result in vacuous institutions (Dimitrov 2005). Finally, a norm's life-cycle involves emergence, cascading (unleashed by a tipping point), and internalization (Finnemore and Sikkink 1998) (here, we use the term institutionalization for the third stage).

Considering the UNFCCC context as the most important arena for norm-setting in relation to adaptation, we propose here that the norm of adaptation as a primarily local and/ or national concern and responsibility became firmly institutionalized at an early stage of international climate politics, which reinforced the framing of territorial adaptation put forward by the dominant epistemic community (see above). Although we agree with Moore (2012, p. 33) that there is "no firmly embedded set of norms yet governing [the] implementation [of adaptation]" in the negotiations (e.g. relating to what kind of adaptation is prioritized or how much adaptation is "adequate"), we argue that a norm specifically regulating appropriate scale and responsible government level was indeed firmly established and institutionalized. This norm was further diffused to - and institutionalized by - countries, and not contested until the preparations for the Paris Agreement.

This norm emerged with the establishment of the 1992 UNFCCC Convention text: "All Parties shall... formulate, implement, publish and regularly update national and, where appropriate, regional programmes containing measures to mitigate climate change... and measures to facilitate adequate adaptation to climate change" (Article 4.1(b), our italics). National governments (i.e. Parties) were thus seen as the responsible agents to facilitate adaptation and to develop national (and possibly regional) programmes. This norm was in line with the broader norm in global environmental governance since 1972 to protect and promote state sovereignty (Bernstein 2013).

A "tipping point" for norm cascading and institutionalization was the requirement for Parties to include adaptation in their National Communications (NCs) to the UNFCCC (Article 12.1). NCs are due every fourth year, with special guidelines for Annex I and nonannex I countries, respectively. ${ }^{3}$ The official guidance refers to reporting on national vulnerability assessment and national adaptation measures, and leeway is given to use "methodologies and guidelines they consider better able to reflect their national situation". ${ }^{4}$ The technical guidelines referred to are agnostic about geographical scale of climate impacts as well as adaptation options (see Carter et al. 1994; Feenstra et al. 1998), but the UNFCCC context meant that the national scale was dominant.

The national scale was further institutionalized with the introduction of NAPAs ${ }^{5}$ in 2001, a vehicle by which Least Developed Countries received financial support to prioritize adaptation options, to be put forward for funding by the Global Environment Facility.

\footnotetext{
${ }^{3}$ Decision 4/CP.5 and Decision 17/CP.18.

${ }^{4}$ Decision 17/CP.18, p. 7.

${ }^{5}$ Decision 5/CP.7 and 7/CP.7.
} 
A series of national planning provisions have followed. NAPAs were succeeded by NAPs ${ }^{6}$ in 2010 as a vehicle for all developing countries to plan adaptation and receive financial support for the process of doing so. Both NAPAs and NAPs act as foundations for national governments to seek multilateral and bilateral funding for adaptation measures. NAPAs and NAPs have a clear national scope, with technical guidance that refers to, inter alia, the importance of being country-driven, providing country background information, consulting with national stakeholders, and aligning with other national development strategies (Least Developed Countries Expert Group 2002, 2012). The guidance asks as key questions: "Which climatic patterns in the country, according to observed data, are most important in terms of adjustment, adaptation or acclimatization of social systems? What risks does climate change hold for the country?" (p. 56, our italics).

This norm privileging the national-level and territorial framing cascaded through the international system, with OECD countries starting to develop NASs in 2005 and the European Commission encouraging their development by member states from 2009 (see above).

At the same time as this norm-underpinned by principles of state sovereignty and subsidiarity—served to "scale down" adaptation governance responsibilities in the international system, efforts were also made from an early stage to "scale up" adaptation to the international level (cf. Gupta 2008). Specifically, these efforts were about recognizing an international responsibility to provide financial support for undertaking adaptation at a national or local level in developing countries. The norm that developed countries should support adaptation in developing countries was institutionalized already in the Convention (Articles 4.3 and 4.4). It became further elevated with time, through the Bali Action Plan and the Copenhagen Accord (see e.g. Verheyen 2002; Khan and Roberts 2013). Moore (2012) describes this as an "adaptation as development" norm being contested by an "adaptation as restitution" norm. Note, however, that the intention of this international responsibility was to fund adaptation, not $d o$ adaptation-i.e. a means to an end.

Clearly, this norm of international responsibility to fund adaptation has been at least partly successful, through the establishment of multilateral funding institutions such as the Adaptation Fund, the Green Climate Fund, Least Developed Countries Fund, Special Climate Change Funds, and the Pilot Program on Climate Resilience. However, the focus of these funds is still primarily on adaptation at the national level, with national governments as key agents and as eligible entities to seek funding or endorse applications. It could be argued that international adaptation finance institutions engage in not only funding adaptation but also governing how adaptation is practiced, through the rules pertaining to eligible and desirable adaptation activities. The extent to which this is the case needs further empirical analysis, but in the context of the argument made here, it seems that the territorial and national-level framing of adaptation still holds, even if it is governed from an international level.

In the context of adaptation funding, the norm outlined above: that adaptation is a local and national responsibility, seems to have been reinforced by another norm, namely the need to demonstrate causality and attribute adaptation measures solely to impacts resulting from climate change and nothing else. For example, applicants to the Adaptation Fund need to demonstrate the vulnerability of local communities to place-based impacts, and local climate change projections are encouraged (Remling and Persson 2015). Adaptation funding from the Global Environment Facility initially required applicants to demonstrate and cost "additionality", i.e. the additional level of investment needed to make a project

\footnotetext{
${ }^{6}$ Decision 5/CP.17.
} 
adapted - not to climate variability, but to climate change (Klein and Möhner 2009). The importance of highlighting the "climate rationale" behind adaptation finance continues to be emphasized in international processes that govern adaptation, most noticeably at the Green Climate Fund (GCF 2018). It is easier to establish a causal link between key risks or proposed adaptation measures and "direct" impacts within country borders than it is to attribute them to spatially more diffuse and borderless climate risks (cf. Challinor et al. 2018).

Thus, it appears that the norm that adaptation is a local and national responsibility was effectively diffused and institutionalized within the UNFCCC regime, and cascaded beyond it. While this norm, and the norm of international responsibility for funding adaptation, have been strongly institutionalized (although the latter more contested, see Moore 2012), an overarching norm spelling out what kind of and how much adaptation should be undertaken is conspicuously missing. This is particularly clear when compared to norms regarding climate mitigation (Hall and Persson 2018). It has similarities with the findings by Dimitrov (2005) regarding the creation of an international forestry institution. This institution was rather the result of a "norm of environmental multilateralism", defined as "the collective expectation that governments address global ecological issues in a collective, multilateral manner" (p. 3), rather than clear norms regarding appropriate forestry behaviour. While we would not characterize international adaptation institutions as "hollow", after Dimitrov, it can certainly be argued that they are characterised by ambiguity.

In the lead-up to negotiations of a post-2020 agreements, however, the norm that adaptation is only a local or national responsibility was questioned by scholars pointing to, inter alia, the importance of borderless climate risks (Khan 2013; Magnan et al. 2015; Khan and Roberts 2013; Ford et al. 2015), as well as by Parties in the regime. After lobbying by the African Group and parts of civil society, the Paris Agreement now includes a "global goal" on adaptation (Article 7.1) and adaptation is for the first time explicitly recognized as a "global challenge faced by all with local, subnational, national, regional and international dimensions" (Article 7.2, emphasis added). This indicates that consideration of borderless climate risk might increase and adaptation may become framed in less territorial ways.

While we clearly see opportunities in the tentative evolution of the scale-framing of adaptation from national to supra-national, it is also worthwhile to point out the potential dangers or pitfalls of re-framing adaptation in this way. Equity, historical responsibility and support for the most vulnerable countries have been the key rationales for international cooperation on adaptation, especially in the pre-Paris era (Khan and Roberts 2013). At least in theory, there is a danger that a borderless framing of climate risk stimulates countries to adopt an approach to cooperation on adaptation that is based solely on narrow self-interest, for example by prioritizing the allocation of bilateral adaptation finance in ways that minimize the donor's own exposure to borderless climate risks. This would be an undesirable outcome. It may, for example, lead to the diversion of limited adaptation funds to countries with strategic links to donor countries (e.g. middle income countries that are key high value exporters), rather than the most vulnerable countries, who may be relatively less connected to donors (e.g. at lower tiers of supply chains). Vigilance is therefore needed to ensure that the adoption of a borderless framing does not undermine the primacy of equity and other rationales for international cooperation on adaptation (see also Roggero et al. 2019, for a distinction between an ethical rationale vs. a cross-boundary spillover rationale). Instead, a borderless framing should be seen as an additional rationale for why increased cooperation and investments in global adaptation are necessary and worthwhile. 


\section{Implications for governing borderless climate risks}

Other theoretical perspectives could provide complementary or alternative explanations of the dominance of the territorial framing of adaptation where borderless climate risks do not fit easily. For example, border studies in political geography describe the role of the state in simplifying complexity and how borders help bring order to analysis and governance (Scott 1998; Newman 2006; see also Beck and Sznaider 2010; Beck et al. 2013). Further, the concept of "institutional fit" developed in the social-ecological systems literature notes the discrepancy between environment risks and the governance mechanisms called upon to manage those risks (see e.g. Cox 2012; Folke et al. 2007). Our main point here is that adaptation is an ambiguous policy challenge and, as such, issue framing disproportionately shapes the kinds of governance choices that are preferred and pursued (Massey et al. 2015; Huitema et al. 2016).

Additionally, the sheer complexity implied by "non-territorial" framings of adaptation cannot be underestimated as an explanatory factor of the dominance of more place-based approaches. Understanding globally networked risk is not an easy undertaking for research, and adaptation assessments typically need to balance depth and breadth (Feenstra et al. 1998). Basing policy decisions on framings of risks as networked and global also poses challenges of additional and deep uncertainty, increasing the likelihood that decision-makers will prefer simpler framings of the same issue.

As alluded to above, we observe in recent years increasing contestation of the territorial framing of adaptation and increasing interest in understanding borderless climate risks. First, the epistemic community is arguably being expanded to include more economics, supply chain analysis, finance, migration and security expertise (see national assessments referred to below). Second, the norm that adaptation is a local and national responsibility is being challenged, both (i) from within the climate regime, through the explicit recognition of adaptation as also a global-scale challenge in the Paris Agreement, and (ii) from outside the climate regime, through the interest from security institutions in climate risk (Dellmuth et al. 2018) and ideas concerning global risk management more generally (see e.g. Galaz et al. 2017; Helbing 2013; World Economic Forum 2019). Based on these observations, and drawing on Khan's (2016) seminal discussion of adaptation governance through key IR perspectives, we outline below some of the main options for increasing the consideration of borderless climate risk in adaptation governance: national and bilateral governance; transnational governance; and international and regional governance. These complementary options are summarized in Table 2. We call on the IR scholarship, as well as adaptation policy community, to engage in more in-depth evaluation of these options.

\subsection{National and bilateral governance responses}

Taking a realist perspective, and assuming that states are sovereign and unitary rational actors that maximize their interests in world politics, national governments choose whether or not to engage with borderless climate risks in their national adaptation planning. Taking action would depend on the perceived cost-benefit ratio of adapting to borderless climate risks. From a liberalist perspective, where peace and harmony among states is seen as important for well-functioning markets, a laissez-faire approach towards borderless climate risks can be justified. This perspective appears to align with the idea of autonomous adaptation, i.e. that markets will automatically adapt to changing risks and opportunities (see 


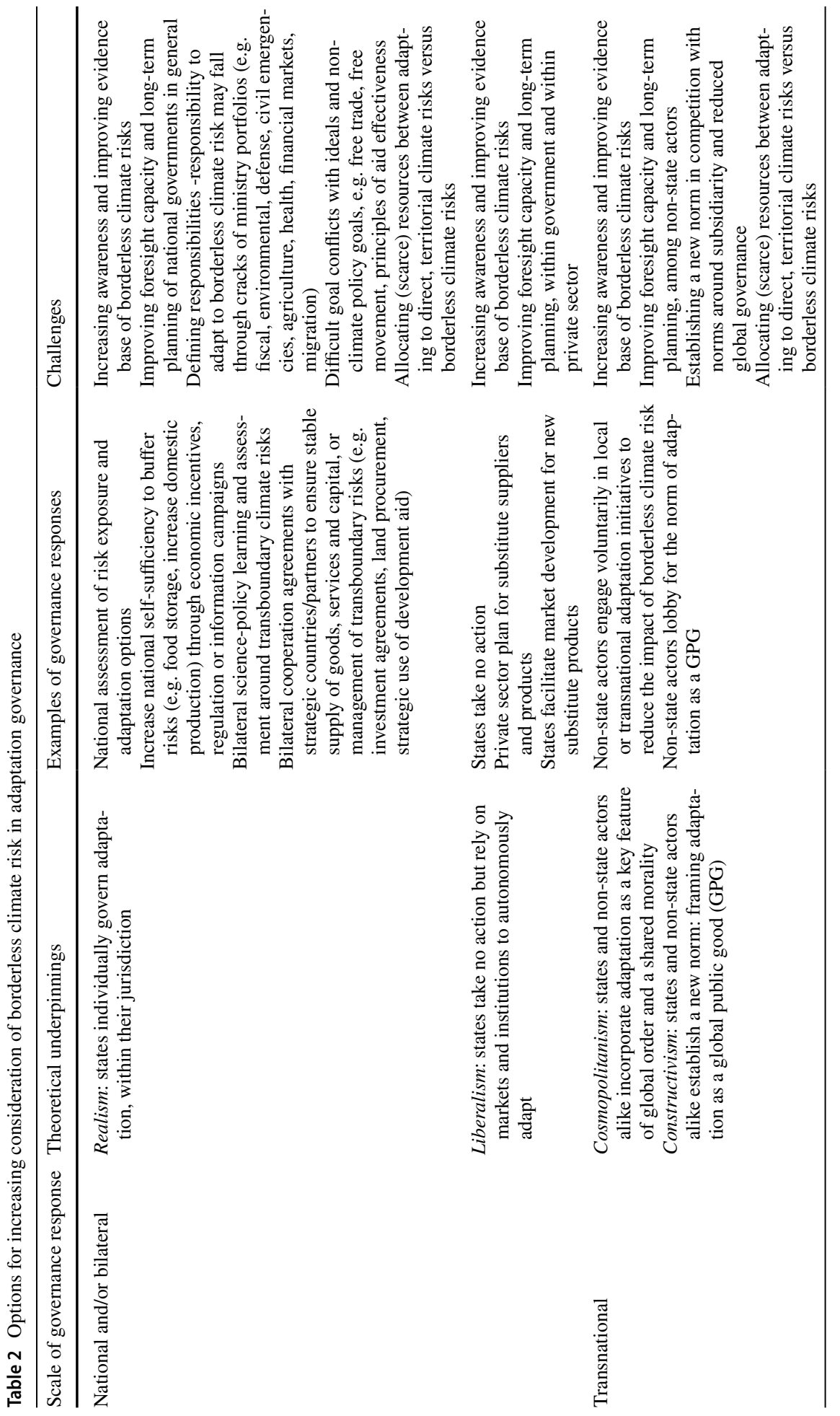




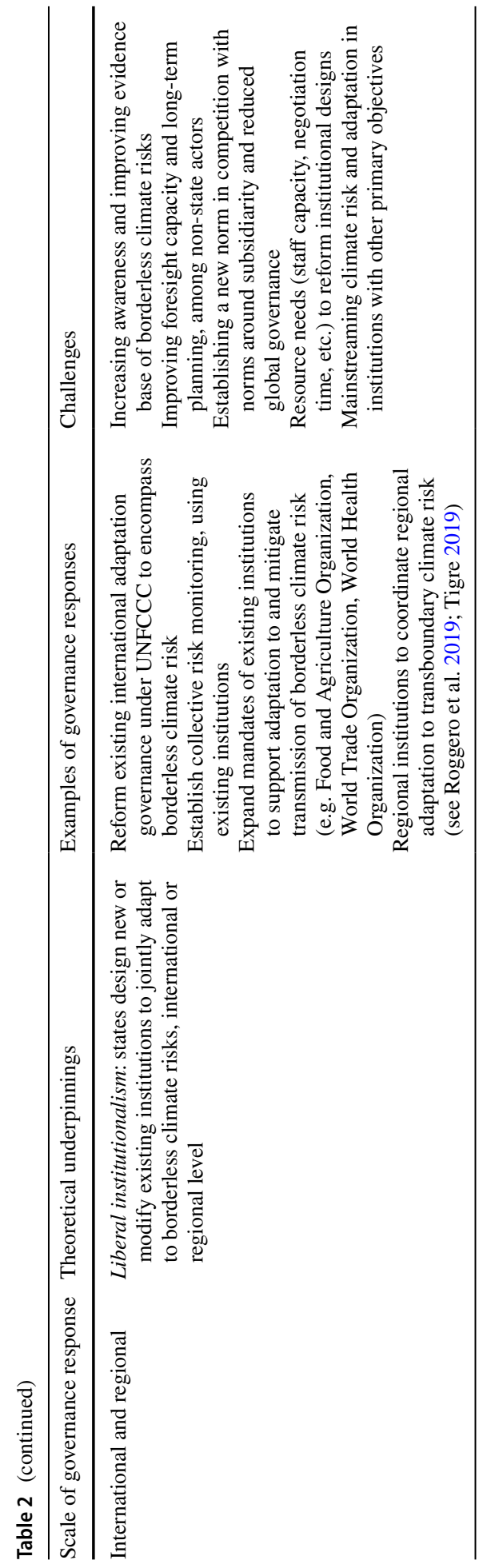


e.g. Juliá and Duchin 2007). Neither of these courses of action necessitate a contestation of the dominant norm at the international level, that adaptation is primarily national or local.

We identify three types of national and bilateral responses to governing borderless climate risks: undertaking national assessments of risks, exposure and governance options (see below); arranging bilateral science-policy social learning processes (Wilder et al. 2010); and developing informal or formal bilateral cooperation agreements with countries that may transmit risk or offer positive adaptation spillovers (e.g. investment agreements, land procurement, strategic use of development aid) (Schenker and Stephan 2014). The latter option is similar to the idea of "side payments" or "issue linkage" (Roggero et al. 2019). Note that these are just types of responses, and the extent to which they avoid sub-optimal or mal-adaptation for either the country in question or the international system depends on the design of concrete governance measures.

As an initial response, national assessments are now being increasingly undertaken by countries, under different banners and of varying official status: Finland (Kankaanpää and Carter 2007), Canada (Bruce and Haites 2008), the UK (Hunt et al. 2009; Government Office for Science 2011; Paul Watkiss Associates 2012; PWC 2013; Challinor et al. 2018), Sweden (Andersson et al. 2016), Kenya (Government of Kenya 2012), Nauru (Government of the Republic of Nauru 2015), the USA (Smith et al. 2018), Norway (Climate Risk Commission 2018) and China (Committee on Climate Change and China Expert Panel on Climate Change 2018). From these, we make a few observations: quantification of transnational impacts has proven difficult; a variety of methodological approaches have been taken, relying to varying degrees on climate science as a starting point, or assessments of national characteristics that may increase exposure to borderless risks; all studies call for more research and note the limits of existing evidence; and few of the studies make concrete recommendations for adaptation to borderless climate risks based on their analysis.

We propose that a systemic barrier needs to be addressed to further enhance national and bilateral governance of borderless climate risks. Nation states have not typically been successful in developing functions and clear responsibilities for managing external risks at the strategic level. Many governments work to short policy cycles, and powerful ministries are therefore more concentrated on short-term risks. Recognizing this shortfall, several governments have created foresight functions to perform "horizon scanning" and strategic risk functions. However, many of these exist temporarily, outside the established Departmental structure of government, and rarely do they outlast the governments or political leaders who first established them, something which has been identified as a major weakness for strategic risk foresight by WEF (2016).

\subsection{Transnational responses}

From a cosmopolitan perspective, Khan (2016, p. 18) argues that a more globalized framing of adaptation goes together with ideas of a "global order based on justice, human rights and international law" and "one in which non-state actors play an increasingly important role". He proposes, adding a constructivist perspective, a new norm of considering adaptation as a global public good (GPG). GPGs would be defined broadly, as not only global natural commons but also human-made (global networks, knowledge, international regimes) and policy outcomes and conditions (peace, security, financial stability) (Kaul et al. 1999, in Khan 2016). Note that this definition is much more expansive than that proposed by Roggero et al. (2019), in that adaptation could contribute to the provision of these 
GPGs rather than constituting a GPG itself (through cross-boundary spillovers). Many borderless risks (but not necessarily all) would fall within this definition.

Clearly, such a norm would drastically redefine interests of states and of international institutions, but also — arguably_many non-state actors' interest. Non-state actors with an interest in borderless climate risk, as an element of adaptation as a GPG, could include: businesses, whose cross-border supply chains are at risk (see e.g. CDP 2019); investors and financial institutions, whose overseas investments are at risk (see e.g. TCFD 2017); nongovernmental organizations (NGOs), whose work focuses on global commons or particular places that are at high risk. Non-state actors can also play a role in promoting such a norm towards a tipping point where it could potentially become more formally institutionalized (see below; cf. Finnemore and Sikkink 1998). Aside from a cosmopolitan and constructivist perspective implying that non-state actors engage out of a normative concern, there may also be functional rationales in that state actors are not fulfilling certain governance functions (Chan and Amling 2019).

Considering that states have limitations in governing long-term and complex risks (see above), we identify a significant role for non-state actors in the governance of borderless climate risks, to engage in transnational governance (with or without state actors). We further identify two types of responses. First, with an increased awareness of borderless climate risks and their dependencies upon global commons, we can expect more non-state actors to take governance initiatives that cross borders, through transnational partnerships (see Chan and Amling 2019; Dzebo 2019). Second, non-state actors are already engaging in transnational adaptation governance, but with a focus on direct climate risks and impacts within country borders (Dzebo and Stripple 2015; Papin 2019). Thus, they operate already within the territorial framing of adaptation. Such de facto governance arrangements, while sometimes not addressing borderless climate risks, can help sensitize non-traditional, nonstate actors to adaptation and to gradually expand their scope when undertaking climate risk assessment to increasingly consider also borderless risks.

\subsection{International and regional governance responses}

Finally, taking a liberal institutionalist perspective, it strongly matters whether new norms are accepted and embedded in international institutions (at global or regional level), since these institutions are considered to be "a force in global politics" (Khan 2016, p. 16). The global goal on adaptation, now embedded under the UNFCCC, may more effectively incorporate borderless climate risk in the framing of adaptation and even contribute to the institutionalization of a new norm of adaptation as a GPG. However, it is yet too early to say, since the follow-up and manifestation of this goal will not become evident until the first "global stock-take" in 2023 (Hall and Persson 2018).

Whereas regional governance of borderless climate risks seems to evolve more naturally and can be modelled on existing transboundary cooperation (e.g. around shared water resources) (see Roggero et al. 2019; Tigre 2019), two overarching questions of institutional design at the international level arise as the territorial framing of adaptation is increasingly contested. First, what kind of powers should be afforded to international governance initiatives and how strong should they be? Here, we see a difference between arguments for a separate adaptation protocol (Khan 2013) and for an "optimal" approach characterized by the subsidiarity principle and avoidance of "over-reach" and overlap with existing international law (Banda 2018). Second, to what extent should existing climate change-oriented international institutions (i.e. the UNFCCC) be strengthened, as opposed to mainstreaming 
of climate adaptiveness as a horizontal norm across all international institutions in multiple sectors (Biermann 2014)?

These overarching questions require more IR - as well as multi-disciplinary-research. But we nevertheless pragmatically identify three broad types of international governance responses. First, existing instruments and provisions under the UNFCCC can be reformed to better encompass borderless climate risk. This includes, e.g. broadening the scope of NAPs, Adaptation Communications and NC guidance; ensuring assessment of borderless climate risk in the global stock-take by Parties and third Parties; and ensuring expertise in the Adaptation Committee (Benzie et al. 2018). Second, collective risk monitoring can be intensified in existing institutions responsible for specific issue areas (e.g. FAO for food security) (Committee on Climate Change and China Expert Panel on Climate Change 2018). Third, significantly stronger mandates or new institutions can be considered. For example, we note that the UN Security Council has increasingly referred to climate security and central banks are called upon to prepare for climate risk. Already, multiple governance domains are engaging with climate risk to their respective issue areas, e.g. migration, development, security, disaster risk and reduction, health (see e.g. Dellmuth et al. 2018; Hall 2015). This is far from the "legal transformation" model put forward by Galaz et al. (2014), but may represent incremental change.

\section{Conclusion}

With the increasing recognition of borderless climate risks, adaptation governance is confronting new questions about design and effectiveness. The aim of this paper was to explain why the territorial framing of adaptation has dominated for so long, and what the governance responses might be to better deal with borderless climate risks. In summary, we propose that the epistemic community that developed to interpret climate change adaptation for decision-makers had certain features (e.g. strong environmental sciences foundation, reliance on place-based case study research) that established and subsequently reinforced the territorial framing. This framing was then reinforced by an international norm that adaptation was primarily a national or local responsibility, which has paradoxically also informed calls for international responsibility for funding adaptation. Not until relatively recently has this framing and associated norm been contested, but now momentum is growing for a more diversified governance approach. In this paper, we sketched governance responses at three different levels — national and bilateral; transnational; international and regional—and invite more systematic evaluation by the IR community.

The prospects for improved governance of borderless climate risks are mixed. On the positive side, demand for knowledge on borderless risks is increasing and the forthcoming sixth IPCC Assessment Report looks likely to synthesise knowledge on this topic, serving as a milestone for its emergence in wider governance discussions. There is interest among various countries, research funders, donors and UNFCCC bodies to investigate the implications of this topic. The upcoming first global stock-take in 2023 could be another milestone showcasing governance activities and policy implications. On the other hand, the burden of administrative and research work required for what this paper calls territorial adaptation is already overwhelming for many countries. Starting to consider adaptation to borderless risks is perhaps a step too far for some, while the prospects of adding this topic to the busy negotiating agenda under the UNFCCC are perhaps low. For this reason, we argue 
that concerted efforts to assess borderless climate risks must be matched by comprehensive capacity-building, in particular to support parts of the world facing "double exposure".

Acknowledgements This research was funded by the Swedish Research Council Formas, Grant No. 2112012-1842 "Climate adaptation in a globalised world" and the Mistra Geopolitics research programme. We are grateful for comments on earlier versions of this paper by participants at the workshop "The emerging complexity of climate adaptation governance in a globalising world", Stockholm, Sweden, May 2017, and the 2017 ISA conference in Atlanta.

\section{Compliance with ethical standards}

Conflict of interest The authors declare that they have no conflict of interest.

Open Access This article is distributed under the terms of the Creative Commons Attribution 4.0 International License (http://creativecommons.org/licenses/by/4.0/), which permits unrestricted use, distribution, and reproduction in any medium, provided you give appropriate credit to the original author(s) and the source, provide a link to the Creative Commons license, and indicate if changes were made.

\section{References}

Adger, W. N. (2001). Scales of governance and environmental justice for adaptation and mitigation of climate change. Journal of International Development, 13(7), 921-931. https://doi.org/10.1002/jid.833.

Adger, W. N., Agrawala, S., Mirza, M. M. Q., Conde, C., O’Brien, K., Pulhin, J., et al. (2007). Assessment of adaptation practices, options, constraints and capacity. In Climate Change 2007: Impacts, adaptation and vulnerability. Contribution of Working Group II to the Fourth Assessment Report of the Intergovernmental Panel on Climate Change, 2007, by IPCC, edited by M. L. Parry, O. F. Canziani, J. P. Palutikof, P. J. van der Linden, and C. E. Hanson (pp. 717-43). Cambridge: Cambridge University Press. http://www.ipcc.ch/publications_and_data/ar4/wg2/en/ch17.html.

Adger, N., Arnell, N., \& Tompkins, E. (2005). Successful adaptation across scales. Global Environmental Change, 15(2), 77-86.

Amundsen, H., Berglund, F., \& Westskog, H. (2010). Overcoming barriers to climate change adaptationA question of multilevel governance? Environment and Planning C: Government and Policy, 28(2), 276-289. https://doi.org/10.1068/c0941.

Andersson, L., Bohman, A., van well, L., Jonsson, A., Persson, G., \& Farelius, J. (2016). Underlag till Kontrollstation 2015 För Anpassning till Ett Förändrat Klimat. SMHI Klimatologi Nr 12. Norrköping: SMHI. http://www.smhi.se/polopoly_fs/1.86346!/Menu/general/extGroup/attachmentColHold/mainC ol1/file/Klimatologi_12.pdf. Accessed 10 March 2016.

Bailey, R., \& Wellesley, L. (2017). Chokepoints and vulnerabilities in global food trade. London: Chatham House.

Banda, M. L. (2018). Global adaptation law: Optimizing legal design for multi-level public goods after the Paris Agreement. Vanderbilt Journal of Transnational Law, 51(4), 997-1026.

Barrett, S. (2007). Why cooperate? The incentive to supply global public goods. Oxford: Oxford University Press.

Barrett, S. (2008). Climate treaties and the imperative of enforcement. Oxford Review of Economic Policy, 24(2), 239-258. https://doi.org/10.1093/oxrep/grn015.

Bauer, A., Feichtinger, J., \& Steurer, R. (2012). The governance of climate change adaptation in 10 OECD countries: Challenges and approaches. Journal of Environmental Policy \& Planning, 14(3), 279-304. https://doi.org/10.1080/1523908X.2012.707406.

Beck, U., Blok, A., Tyfield, D., \& Zhang, J. Y. (2013). Cosmopolitan communities of climate risk: Conceptual and empirical suggestions for a new research agenda. Global Networks, 13, 1.

Beck, U., \& Sznaider, N. (2010). Unpacking cosmopolitanism for the social sciences: A research agenda. The British Journal of Sociology, 57, 1-23.

Benzie, M. (2014). National adaptation plans and the indirect impacts of climate change. SEI Policy Brief. http://www.sei-international.org/publications?pid=2624. Accessed 10 January 2017.

Benzie, M., Adams, K., Roberts, E., Magnan, A., Persson, A., Nadin, R., et al. (2018). Meeting the global challenge of adaptation by addressing transboundary climate risk. Discussion Brief. Stockholm: 
Stockholm Environment Institute. https://www.sei.org/publications/transboundary-climate-risk/. Accessed 10 January 2017.

Benzie, M., \& John, A. (2015). Reducing vulnerability to food price shocks in a changing climate. SEI Policy Brief. Stockholm: SEI. http://www.sei-international.org/publications?pid=2657. Accessed 10 January 2017.

Bernstein, S. (2013). Global environmental norms. In R. Falkner (Ed.), The handbook of global climate and environment policy. London: Wiley.

Biermann, F. (2014). Earth system governance: World politics in the Anthropocene. Cambridge: MIT Press.

Biesbroek, G. R., Swart, R. J., Carter, T. R., Cowan, C., Henrichs, T., Mela, H., et al. (2010). Europe adapts to climate change: Comparing national adaptation strategies. Global Environmental Change, 20(3), $440-450$.

Blitzer, J. (2019). How climate change is fuelling the U.S. Border Crisis I The New Yorker. New Yorker, 3 April 2019. https://www.newyorker.com/news/dispatch/how-climate-change-is-fuelling-the-usborder-crisis. Accessed 10 May 2019.

Blumstein, S., Pohl, B., \& Tänzler, D. (2016). Water and climate diplomacy: Integrative approaches for adaptive action in transboundary river basins. Berlin: Adelphi.

Bruce, J., \& Haites, E. (2008). Canada in an international context. In From impacts to adaptation: Canada in a changing climate 2007, edited by Donald Lemmen, Fiona Warren, Jacinthe Lacroix, and Elizabeth Bush. Ottawa: Government of Canada. http://www.nrcan.gc.ca/environment/resources/ publications/impacts-adaptation/reports/assessments/2008/10253.

Carter, T. R., Parry, M. L., Harasawa, H., \& Nishioka, S. (1994). IPCC technical guidelines for assessing climate change impacts and adaptations. London: University College London.

CDP. (2019). Cascading commitments: Driving ambitious action through supply chain engagement. CDP Supply Chain Report 2018/19. London: CDP.

Challinor, A. J., Adger, W. N., \& Benton, T. G. (2017). Climate risks across borders and scales. Nature Climate Change, 7(9), 621-623. https://doi.org/10.1038/nclimate3380.

Challinor, A. J., Adger, W. N., Benton, T. G., Conway, D., Manoj, J., \& Frame, D. (2018). Transmission of climate risks across sectors and borders. Philosophical Transactions of the Royal Society A: Mathematical, Physical and Engineering Sciences, 376(2121), 20170301. https://doi.org/10.1098/ rsta.2017.0301.

Chan, S., \& Amling, W. (2019). Does orchestration in the global climate action agenda effectively prioritize and mobilize transnational climate adaptation action? International Environmental Agreements: Politics, Law and Economics, https://doi.org/10.1007/s10784-019-09444-9.

Ciplet, D. (2015). Rethinking cooperation: Inequality and consent in international climate change politics. Global Governance, 21(2), 247-274.

Climate Risk Commission. (2018). Climate risk and the Norwegian economy. Official Norwegian Reports NOU 2018:17 Summary. Oslo: Government of Norway.

Committee on Climate Change and China Expert Panel on Climate Change. (2018). UK-China co-operation on climate change risk assessment: Developing indicators of climate risk. https://www.thecc c.org.uk/wp-content/uploads/2018/10/Developing-Indicators-of-Climate-Risk-Full-Report.pdf. Accessed 15 December 2018.

Cox, M. (2012). Diagnosing institutional fit: A formal perspective. Ecology and Society, 17(4), 54. https ://doi.org/10.5751/ES-05173-170454.

Dellmuth, L. M., Gustafsson, M.-T., Bremberg, N., \& Mobjörk, M. (2018). Intergovernmental organizations and climate security: Advancing the research agenda. Wiley Interdisciplinary Reviews: Climate Change, 9(1), e496. https://doi.org/10.1002/wcc.496.

Dimitrov, R. S. (2005). Hostage to norms: States, institutions and global forest politics. Global Environmental Politics, 5(4), 1-24.

Dovers, S., \& Hezri, A. (2010). Institutions and policy processes: The means to the ends of adaptation. WIREs Climate Change, 1, 212-231.

Dzebo, A. (2019). Effective governance of transnational adaptation initiatives. International Environmental Agreements: Politics, Law and Economics, https://doi.org/10.1007/s10784-019-09445-8.

Dzebo, A., \& Stripple, J. (2015). Transnational adaptation governance: An emerging fourth era of adaptation. Global Environmental Change, 35(November), 423-435. https://doi.org/10.1016/j.gloen vcha.2015.10.006.

EEA. (2017). Climate change, impacts and vulnerability in Europe 2016: An indicator-based report. EEA Report No 1/2017. Publication. Copenhagen: EEA. https://www.eea.europa.eu/publications/ climate-change-impacts-and-vulnerability-2016. Accessed 10 July 2017.

Feenstra, J., Burton, I., Smith, J. B., \& Tol, R. (1998). UNEP handbook on methods for climate change impact assessment and adaptation strategies. Nairobi: UNEP. 
Finnemore, M., \& Sikkink, K. (1998). International norm dynamics and political change. International Organization, 52(4), 887-917.

Folke, C., Pritchard, L., Berkes, F., Colding, J., \& Svedin, U. (2007). The problem of fit between ecosystems and institutions: Ten years later. Ecology and Society, 12(1), 30.

Ford, J. D., Berrang-Ford, L., Biesbroek, R., Araos, M., Austin, S. E., \& Lesnikowski, A. (2015). Adaptation tracking for a post-2015 climate agreement. Nature Climate Change, 5(11), 967-969. https ://doi.org/10.1038/nclimate2744.

Galaz, V., Galafassi, D., Tallberg, J., Boin, A., Hey, E., Ituarte-Lima, C., et al. (2014). Connected risks, connected solutions. Stockholm: Stockholm Resilience Centre, Stockholm University, and the Global Challenges Foundation.

Galaz, V., Tallberg, J., Boin, A., Ituarte-Lima, C., Hey, E., Olsson, P., et al. (2017). Global governance dimensions of globally networked risks: The state of the art in social science research. Risk, Hazards \& Crisis in Public Policy, 8(1), 4-27. https://doi.org/10.1002/rhc3.12108.

GCF. (2018). Steps to enhance the climate rationale of GCF-supported activities, GCF Board Meeting notes GCF/B.21/Inf.08. https://www.greenclimate.fund/documents/20182/1270184/GCF_B.21_Inf.08_-_ Steps_to_enhance_the_climate_rationale_of_GCF-supported_activities.pdf/625a3b8c-d0b2-792eb587-3ecdd2230a96. Accessed 20 April 2019.

Glaas, E., \& Juhola, S. (2013). New levels of climate adaptation policy: Analyzing the institutional interplay in the Baltic Sea region. Sustainability, 5(1), 256-275. https://doi.org/10.3390/su5010256.

Goldin, I., \& Mariathasan, M. (2014). The butterfly defect: How globalization creates systemic risks, and what to do about it. Princeton: Princeton University Press.

Government of Kenya. (2012). National Climate Change Action Plan: Adaptation-Technical Analysis Report. November 2012. http://www.kccap.info/index.php?option=com_phocadownl oad\&view=category\&id=30:adaptation-analysis. Accessed 10 January 2017.

Government of the Republic of Nauru. (2015). Framework for climate change adaptation and disaster risk reduction—RONAdapt. http://reliefweb.int/sites/reliefweb.int/files/resources/NRU_2015_RONAd apt_Framework.pdf. Accessed 10 January 2017.

Government Office for Science. (2011). International dimensions of climate change: Final project report. London: The Government Office for Science. https://www.gov.uk/government/publications/internatio nal-dimensions-of-climate-change. Accessed 10 November 2016.

Grothmann, T. (2014). Adaptation research: Where do we stand and where should we go? In A. Prutsch, T. Grothmann, S. McCallum, I. Schauser, \& R. J. Swart (Eds.), Climate change adaptation manual: Lessons learned from European and other industrialised countries. London: Routledge.

Gupta, J. (2008). Global change: Analyzing scale and scaling in environmental governance. In O. R. Young, L. King, \& H. Schroeder (Eds.), Institutions and environmental change: Principal findings, applications, and research frontiers. Cambridge MA: The MIT Press.

Haas, P. M. (1992). Introduction: Epistemic communities and international policy coordination. International Organization, 46(01), 1-35. https://doi.org/10.1017/S0020818300001442.

Hall, N. (2015). Money or mandate? Why international organizations engage with the climate change regime. Global Environmental Politics, 15(2), 79-97.

Hall, N., \& Persson, A. (2018). Global climate adaptation governance: Why is it not legally binding? European Journal of International Relations, 24(3), 540-566. https://doi.org/10.1177/1354066117725157.

Hedlund, J., Fick, S., Carlsen, H., \& Benzie, M. (2018). Quantifying transnational climate impact exposure: New perspectives on the global distribution of climate risk. Global Environmental Change, 52(September), 75-85. https://doi.org/10.1016/j.gloenvcha.2018.04.006.

Helbing, D. (2013). Globally networked risks and how to respond. Nature, 497(7447), 51. https://doi. org/10.1038/nature12047.

Huitema, D., Adger, W. N., Berkhout, F., Massey, E., Mazmanian, D., Munaretto, S., et al. (2016). The governance of adaptation: Choices, reasons, and effects. Introduction to the special feature. Ecology and Society, 21(3), 37. https://doi.org/10.5751/ES-08797-210337.

Hunt, A., Watkiss, P., \& Horrocks, L. (2009). International impacts of climate change on the UK. Report to DEFRA. http://randd.defra.gov.uk/Document.aspx?Document=GA0208_8177_FRP.pdf. Accessed 10 January 2017.

Incropera, F. (2015). Climate change: A wicked problem. Complexity and uncertainty at the intersection of science, economics, politics, and human behavior. New York: Cambridge University Press. http:// www.cambridge.org/us/academic/subjects/earth-and-environmental-science/climatology-and-clima te-change/climate-change-wicked-problem-complexity-and-uncertainty-intersection-science-econo mics-politics-and-human-behavior. Accessed 10 January 2017.

IPCC. (2001). Climate Change 2001: Impacts, adaptation and vulnerability. New York: Cambridge University Press. 
IPCC. (2007). Climate Change 2007: Impacts, adaptation and vulnerability. Contribution of Working Group II to the Fourth Assessment Report of the Intergovernmental Panel on Climate Change, 2007. Edited by Martin L. Parry, Osvaldo F. Canziani, Jean P. Palutikof, Paul J. van der Linden, and Clair E. Hanson. Cambridge: Cambridge University Press. http://www.ipcc.ch/publications_and_data/ar4/ wg2/en/contents.html.

IPCC. (2014). Climate Change 2014: Impacts, adaptation, and vulnerability. Part A: Global and sectoral aspects. Contribution of Working Group II to the Fifth Assessment Report of the Intergovernmental Panel on Climate Change [Field, C.B., V.R. Barros, D.J. Dokken, K.J. Mach, M.D. Mastrandrea, T.E. Bilir, M. Chatterjee, K.L. Ebi, Y.O. Estrada, R.C. Genova, B. Girma, E.S. Kissel, A.N. Levy, S. MacCracken, P.R. Mastrandrea, and L.L. White (Eds.)]. Cambridge: Cambridge University Press.

Juhola, S., Keskitalo, E. C. H., \& Westerhoff, L. (2011). Understanding the framings of climate change adaptation across multiple scales of governance in Europe. Environmental Politics, 20(4), 445-463. https://doi.org/10.1080/09644016.2011.589571.

Juliá, R., \& Duchin, F. (2007). World trade as the adjustment mechanism of agriculture to climate change. Climatic Change, 82(3-4), 393-409. https://doi.org/10.1007/s10584-006-9181-8.

Kankaanpää, S., \& Carter, T. R. (2007). Implications of international climate change impacts for Finland. Unpublished Report by the Finnish Environment Institute Submitted to the Ministry of Environment, Finland.

Keskitalo, E. C. H. (2009). Governance in vulnerability assessment: The role of globalising decision-making networks in determining local vulnerability and adaptive capacity. Mitigation and Adaptation Strategies for Global Change, 14(2), 185-201. https://doi.org/10.1007/s11027-008-9159-0.

Keskitalo, E. C. H. (Ed.). (2010). Developing adaptation policy and practice in Europe: Multi-level governance of climate change. Dordrecht: Springer.

Khan, M. R. (2013). Toward a binding climate change adaptation regime: A proposed framework (1st ed.). London: Routledge.

Khan, M. (2016). Climate change, adaptation and international relations theory. In E. Atkins \& G. SosaNunez (Eds.), Environment, climate change and international relations (pp. 14-28). Bristol: E-International Relations Publishing.

Khan, M. R., \& Roberts, J. T. (2013). Adaptation and international climate policy. Wiley Interdisciplinary Reviews: Climate Change, 4(3), 171-189. https://doi.org/10.1002/wcc.212.

Khanna, P. (2016). Connectography: Mapping the future of global civilization. New York: Random House.

Klein, R. J. T., \& Juhola, S. (2014). A framework for Nordic actor-oriented climate adaptation research. Environmental Science \& Policy, 40(June), 101-115. https://doi.org/10.1016/j.envsci.2014.01.011.

Klein, R. J. T., \& Möhner, A. (2009). Governance limits to effective global financial support for adaptation. In W. N. Adger, I. Lorenzoni, \& K. L. O'Brien (Eds.), Adapting to climate change: Thresholds, values, governance. New York: Cambridge University Press.

Least Developed Countries Expert Group. (2002). Annotated guidelines for the preparation of national adaptation programmes of action. Bonn: UNFCCC.

Least Developed Countries Expert Group. (2012). National adaptation plans: Technical guidelines for the national adaptation plan process. Bonn: UNFCCC.

Lesnikowski, A., Ford, J., Biesbroek, R., Berrang-Ford, L., \& Heymann, S. J. (2016). National-level progress on adaptation. Nature Climate Change, 6(3), 261-264. https://doi.org/10.1038/nclimate2863.

Liverman, D. (2015). U.S. National Climate Assessment Gaps and Research Needs: Overview, the economy and the international context. Climatic Change, 135(1), 173-186. https://doi.org/10.1007/s1058 4-015-1464-5.

Magnan, A. K., \& Ribera, T. (2016). Global adaptation after Paris. Science, 352(6291), 1280-1282. https:// doi.org/10.1126/science.aaf5002.

Magnan, A., Ribera, T., \& Treyer, S. (2015). National adaptation is also a global concern. IDDRI Working Paper No 4 June 2015. Paris: IDDRI. http://www.iddri.org/Publications/Collections/Idees-pourle-debat/WP0415_AM\%20TR\%20ST_adaptation\%20global\%20concern.pdf. Accessed 10 January 2017.

Mahony, M., \& Hulme, M. (2012). Model migrations: Mobility and boundary crossings in regional climate prediction. Transactions of the Institute of British Geographers, 37(2), 197-211. https://doi.org/10.11 11/j.1475-5661.2011.00473.x.

Massey, E., \& Huitema, D. (2012). The emergence of climate change adaptation as a policy field: The case of England. Regional Environmental Change, 13(2), 341-352. https://doi.org/10.1007/s1011 3-012-0341-2.

Massey, E., Huitema, D., Garrelts, H., Grecksch, K., Mees, H., Rayner, T., et al. (2015). Handling adaptation policy choices in Sweden, Germany, the UK and the Netherlands. Journal of Water and Climate Change, 6(1), 9-24. https://doi.org/10.2166/wcc.2014.110. 
McCarthy, J., Canziani, O., Leary, N., Dokken, D., \& White, K. (2001). Climate change 2001: Impacts, adaptation, and vulnerability. Cambridge: Cambridge University Press.

McG. Tegart, W.J., Sheldon, G. W., \& Griffiths, D. C. (Eds.) (1990). Climate change: The IPCC impacts assessment. IPCC First Assessment Report, Australian Government Publishing Service, Camberra, Australia, $294 \mathrm{pp}$.

Mimura, N., Pulwarty, R. S., Duc, D. M., Elshinnawy, I., Redsteer, M. H., Huang, H.-Q., et al. (2014). Adaptation planning and implementation. In Climate Change 2014: Impacts, adaptation, and vulnerability. Part A: Global and sectoral aspects. Contribution of Working Group II to the Fifth Assessment Report of the Intergovernmental Panel of Climate Change, edited by C. B. Field, V. R. Barros, D. J. Dokken, K. J. Mach, M. D. Mastrandrea, T. E. Bilir, M. Chatterjee, et al. (pp. 869-98). Cambridge: Cambridge University Press.

Moore, F. C. (2012). Negotiating adaptation: Norm selection and hybridization in international climate negotiations. Global Environmental Politics, 12(4), 30-48. https://doi.org/10.1162/GLEP_a_00138.

Moser, S. C., \& Finzi Hart, J. A. (2015). The long arm of climate change: Societal teleconnections and the future of climate change impacts studies. Climatic Change, 129(1-2), 13-26. https://doi.org/10.1007/ s10584-015-1328-z.

Nalau, J., Preston, B. L., \& Maloney, M. C. (2015). Is adaptation a local responsibility? Environmental Science \& Policy, 48(Supplement C), 89-98. https://doi.org/10.1016/j.envsci.2014.12.011.

Newman, D. (2006). The lines that continue to separate us: Borders in our 'borderless' world. Progress in Human Geography, 30(2), 143-161. https://doi.org/10.1191/0309132506ph599xx.

Noble, I. R., Huq, S., Anokhin, Y. A., Carmin, J., Goudou, D., Lansigan, F. P., et al. (2014). Adaptation needs and options. In Climate Change 2014: Impacts, adaptation, and vulnerability. Part A: Global and sectoral aspects. Contribution of Working Group II to the Fifth Assessment Report of the Intergovernmental Panel of Climate Change, edited by C. B. Field, V. R. Barros, D. J. Dokken, K. J. Mach, M. D. Mastrandrea, T. E. Bilir, M. Chatterjee, et al. (pp. 833-68). Cambridge: Cambridge University Press.

O'Brien, K. L., \& Leichenko, R. M. (2000). Double exposure: Assessing the impacts of climate change within the context of economic globalization. Global Environmental Change, 10(3), 221-232. https://doi. org/10.1016/S0959-3780(00)00021-2.

OECD. (2015). National climate change adaptation: Emerging practices in monitoring and evaluation. Paris: OECD Publishing. https://doi.org/10.1787/9789264229679.

Oppenheimer, M., Campos, M., Warren, R., Birkmann, J., Luber, G., O’Neill, B., et al. (2014). Emergent risks and key vulnerabilities. In Climate Change 2014: Impacts, adaptation, and vulnerability. Part A: Global and sectoral aspects. Contribution of Working Group II to the Fifth Assessment Report of the Intergovernmental Panel of Climate Change, edited by C. B. Field, V. R. Barros, D. J. Dokken, K. J. Mach, M. D. Mastrandrea, T. E. Bilir, M. Chatterjee, et al. (pp. 1039-1099). Cambridge: Cambridge University Press.

Otto, C., Willner, S. N., Wenz, L., Frieler, K., \& Levermann, A. (2017). Modeling loss-propagation in the global supply network: The dynamic agent-based model acclimate. Journal of Economic Dynamics and Control, 83(Supplement C), 232-269. https://doi.org/10.1016/j.jedc.2017.08.001.

Papin, M. (2019). Transnational municipal networks: Harbingers of innovation for global adaptation governance? International Environmental Agreements: Politics, Law and Economics, https://doi.org/10.1007/ s10784-019-09446-7.

Paul Watkiss Associates. (2012). Scoping study: Reviewing the coverage of economic impacts in the CCRA. Report to the Committee on Climate Change, Adaptation Sub-Committee. June 2012. https://www.thecc c.org.uk/archive/aws/ASC/2012\%20report/Filling\%20the\%20Gaps\%20around\%20the\%20CCRA\%20 Working\%20Paper\%20June\%202012\%20FINAL.pdf. Accessed 10 January 2017.

Persson, А. (2011). Institutionalising climate adaptation finance under the UNFCCC and beyond: Could an adaptation "Market” Emerge? SEI Working Paper. Stockholm: SEI. http://www.sei-international.org/ publications?pid=1975. Accessed 10 January 2017.

Persson, A. \& Dzebo, A. (2019). Introduction to the special issue: Global and transnational governance of climate adaptation. International Environmental Agreements: Politics, Law and Economics, https://doi. org/10.1007/s10784-019-09440-z.

Persson, A., Klein, R. J. T., Kehler Siebert, C., Atteridge, A., Müller, B., Hoffmaister, J., et al. (2009). Adaptation finance under a Copenhagen agreed outcome. Stockholm: Stockholm Environment Institute. http:// www.sei-international.org/publications?pid=1309. Accessed 10 January 2017.

Pinsky, M. L., Reygondeau, G., Caddell, R., Palacios-Abrantes, J., Spijkers, J., \& Cheung, W. W. L. (2018). Preparing ocean governance for species on the move. Science, 360(6394), 1189-1191. https://doi. org/10.1126/science.aat2360.

PWC. (2013). International threats and opportunities of climate change for the UK. London: PwC.

Remling, E. (2018). Depoliticizing adaptation: A critical analysis of EU Climate Adaptation Policy. Environmental Politics, 27(3), 477-497. https://doi.org/10.1080/09644016.2018.1429207. 
Remling, E., \& Persson, ̊․ (2015). Who is adaptation for? Vulnerability and adaptation benefits in proposals approved by the UNFCCC adaptation fund. Climate and Development, 7(1), 16-34. https://doi. org/10.1080/17565529.2014.886992.

Ribeiro, M., Losenno, C., Dworak, T., Massey, E., Swart, R., Benzie, M., et al. (2009). Design of guidelines for the elaboration of Regional Climate Change Adaptations Strategies. Study for European Commission DG Environment - Tender DG ENV. G.1/ETU/2008/0093r. Vienna: Ecologic Institute.

Roggero, M., Kähler, L., \& Hagen, A. (2019). Strategic cooperation for transnational adaptation: lessons from the economics of climate change mitigation. International Environmental Agreements: Politics, Law and Economics, https://doi.org/10.1007/s10784-019-09442-x.

Runhaar, H., Wilk, B., Persson, Å., Uittenbroek, C., \& Wamsler, C. (2018). Mainstreaming climate adaptation: Taking stock about "What Works" from empirical research worldwide. Regional Environmental Change, 18(4), 1201-1210. https://doi.org/10.1007/s10113-017-1259-5.

Schenker, O. (2012). Exchanging goods and damages: The role of trade on the distribution of climate change costs. Environmental \& Resource Economics, 54(2), 261-282. https://doi.org/10.1007/s1064 0-012-9593-Z.

Schenker, O., \& Stephan, G. (2014). Give and take: How the funding of adaptation to climate change can improve the donor's terms-of-trade. Ecological Economics, 106(October 2014), 44-55.

Schipper, E. L. F., \& Burton, I. (2009). Understanding adaptation: Origins, concepts, practice and policy. In E. Lisa, F. Schipper, \& I. Burton (Eds.), The Earthscan reader on adaptation to climate change (pp. 1-8). London: Earthscan.

Schultz, K., \& Siriwardane, R. (2015). Depoliticised and technocratic? Normativity and the politics of transformative adaptation. Earth System Governance Working Paper No. 33. Lund: Earth System Governance Project.

Scott, J. C. (1998). Seeing like a state: How certain schemes to improve the human condition have failed. New Haven: Yale University Press.

Sentance, A., \& Betts, R. (2012). International dimensions of climate change. Climate Policy, 12(sup01), S1S5. https://doi.org/10.1080/14693062.2012.735804.

Smit, B., \& Pilifosova, O. (2001). Adaptation to climate change in the context of sustainable development and equity. In Climate Change 2001: Impacts, adaptation and vulnerability: Contribution of Working Group II to the Third Assessment Report of the Intergovernmental Panel on Climate Change, edited by J. J. McCarthy, O. F. Canziani, N. Leary, D. J. Dokken, and K. S. White (pp. 877-912). Cambridge: Cambridge University Press. http://www.grida.no/climate/ipcc_tar/wg2/pdf/wg2TARchap18.pdf.

Smith, J. B., Muth, A., Alpert, J. L., Buizer, J., Cook, A., Dave, J., et al. (2018). Climate effects on U.S. International Interests. In D. R. Reidmiller, C. W. Avery, \& D. R. Easterline (Eds.), Impacts, risks, and adaptation in the United States: Fourth National Climate Assessment (Vol. 2). Washington, DC: US Global Change Research Program.

TCFD. (2017). Final report: Recommendations of the task force on climate-related financial disclosures. TCFD. https://www.fsb-tcfd.org/wp-content/uploads/2017/06/FINAL-TCFD-Report-062817.pdf.

Termeer, C. J. A. M., Dewulf, A., Karlsson-Vinkhuyzen, S. I., Vink, M., \& van Vliet, M. (2016). Coping with the wicked problem of climate adaptation across scales: The five $\mathrm{R}$ governance capabilities. Landscape and Urban Planning, 154(October), 11-19. https://doi.org/10.1016/j.landurbplan.2016.01.007.

Tigre, M. A. (2019). Building a regional adaptation strategy for Amazon countries. International Environmental Agreements: Politics, Law and Economics, https://doi.org/10.1007/s10784-019-09443-w.

UNFCCC. (2015). Progress in the process to formulate and implement national adaptation plans. FCCC/ SBI/2015/INF.11, 12 November 2015. http://unfccc.int/resource/docs/2015/sbi/eng/inf11.pdf. Accessed 20 July 2018.

UNFCCC. (2016). NAPAs received by the secretariat. http://unfccc.int/adaptation/workstreams/national_adapt ation_programmes_of_action/items/4585.php. Accessed 20 July 2018.

Verheyen, R. (2002). Adaptation to the impacts of anthropogenic climate change-The international legal framework. Review of European Community \& International Environmental Law, 11(2), 129.

Walker, B., Barrett, S., Polasky, S., Galaz, V., Folke, C., Engström, G., et al. (2009). Looming global-scale failures and missing institutions. Science, 325, 1345-1346.

Watson, R., Zinyowera, M., \& Moss, R. (Eds.) (1995). Climate Change 1995: Impacts, adaptations and mitigation of climate change: Scientific-technical analyses: Contribution of Working Group II to the Intergovernmental Panel on Climate Change.

WEF. (2016). The global risks report 2016, WEF Insight Report, 11th edn. Geneva: World Economic Forum. http://www3.weforum.org/docs/GRR/WEF_GRR16.pdf. Accessed 10 January 2017.

Weisser, F., Bollig, M., Doevenspeck, M., \& Müller-Mahn, D. (2014). Translating the "adaptation to climate change" paradigm: The politics of a travelling idea in Africa. Geographical Journal, 180(2), 111-119. https://doi.org/10.1111/geoj.12037. 
Wilder, M., Scott, C. A., Pineda Pablos, N., Varady, R. G., Garfin, G. M., \& McEvoy, J. (2010). Adapting across boundaries: Climate change, social learning, and resilience in the U.S.-Mexico Border Region. Annals of the Association of American Geographers, 100(4), 917-928. https://doi.org/10.1080/00045 608.2010 .500235 .

World Economic Forum. (2019). The global risks report 2019 (14th ed.). Geneva: World Economic Forum.

Publisher's Note Springer Nature remains neutral with regard to jurisdictional claims in published maps and institutional affiliations. 